\title{
A single mRNA immunization boosts cross-variant neutralizing antibodies elicited by SARS-CoV-2 infection
}

Leonidas Stamatatos ${ }^{1,2}$, Julie Czartoski ${ }^{1}$, Yu-Hsin Wan ${ }^{1}$, Leah J. Homad ${ }^{1}$, Vanessa Rubin ${ }^{1}$, Hayley Glantz ${ }^{1}$, Moni Neradilek ${ }^{1}$, Emilie Seydoux ${ }^{1}$, Madeleine F. Jennewein ${ }^{1}$, Anna J. MacCamy $^{1}$, Junli Feng ${ }^{1}$, Gregory Mize ${ }^{1}$, Stephen C. De Rosa ${ }^{1,3}$, Andrés Finzi ${ }^{4,5,6}$, Maria P.

Lemos $^{1}$, Kristen W. Cohen ${ }^{1}$, Zoe Moodie ${ }^{1}$, M. Juliana McElrath ${ }^{1,2,7^{*}}$, Andrew T. McGuire ${ }^{1,2,3 *}$

${ }^{1}$ Fred Hutchinson Cancer Research Center, Vaccine and Infectious Disease Division, Seattle, WA, USA

${ }^{2}$ Department of Global Health, University of Washington, Seattle, WA, USA

${ }^{3}$ Department of Laboratory Medicine and Pathology, University of Washington, Seattle, WA, USA

${ }^{4}$ Centre de Recherche du CHUM, Montréal, QC, Canada.

${ }^{5}$ Département de Microbiologie, Infectiologie et Immunologie, Université de Montréal,

Montreal, QC, Canada.

${ }^{6}$ Department of Microbiology and Immunology, McGill University, Montreal, QC, Canada.

${ }^{7}$ Department of Medicine, University of Washington, Seattle, WA, USA

* Correspondence: amcguire@fredhutch.org; 1stamata@fredhutch.org;jmcelrat@fredhutch.org 
medRxiv preprint doi: https://doi.org/10.1101/2021.02.05.21251182; this version posted March 10, 2021. The copyright holder for this preprint (which was not certified by peer review) is the author/funder, who has granted medRxiv a license to display the preprint in perpetuity.

It is made available under a CC-BY-NC-ND 4.0 International license.

\begin{abstract}
Emerging SARS-CoV-2 variants have raised concerns about resistance to neutralizing antibodies elicited by previous infection or vaccination. We examined whether sera from recovered and naïve donors collected prior to, and following immunizations with existing mRNA vaccines, could neutralize the Wuhan-Hu-1 and B.1.351 variants. Pre-vaccination sera from recovered donors neutralized Wuhan-Hu-1 and sporadically neutralized B.1.351, but a single immunization boosted neutralizing titers against all variants and SARS-CoV-1 by up to 1000 -fold.

Neutralization was due to antibodies targeting the receptor binding domain and was not boosted by a second immunization. Immunization of naïve donors also elicited cross-neutralizing responses, but at lower titers. Our study highlights the importance of vaccinating both uninfected and previously infected persons to elicit cross-variant neutralizing antibodies.
\end{abstract}


medRxiv preprint doi: https://doi.org/10.1101/2021.02.05.21251182; this version posted March 10, 2021. The copyright holder for this preprint (which was not certified by peer review) is the author/funder, who has granted medRxiv a license to display the preprint in perpetuity.

It is made available under a CC-BY-NC-ND 4.0 International license .

\section{MAIN}

The SARS-CoV-2 betacoronavirus first emerged in the Hubei Province of China in late 2019 and has since infected over 115 million people and caused over 2.5 million deaths in 192 countries $(1-3)$.

Infection is mediated by the viral spike protein $(\mathrm{S})$ which is comprised of an $\mathrm{S} 1$ domain that contains a N-terminal domain (NTD), a C-terminal domain (CTD), and a receptor binding domain (RBD) which mediates attachment to the entry receptor angiotensin converting enzyme 2 (ACE2), and an S2 domain that contains the fusion machinery (4-8).

Pre-existing immunity to SARS-CoV-2 is associated with protection against re-infection in humans (9-11) and in non-human primates $(12,13)$. Although the correlates of protection in humans against repeat infection or following vaccination have not been firmly established, neutralizing antibodies (nAbs) are thought to be an important component of a protective immune response against SARS-CoV-2 $(14,15)$. In support of this, passive transfer of nAbs limits respiratory tract infection and protects against infection in animal models (16-20) and may contribute to protection against infection in humans (9). SARS-CoV-2 infection rapidly elicits nAbs $(16,21-24)$ that decline, but remain detectable over several months (25-29).

The majority of serum neutralizing antibody responses elicited during natural infection are directed at the receptor bidning domain $(\operatorname{RBD})(21,23,30,31)$. Numerous neutralizing antiRBD monoclonal antibodies (mAbs) have been characterized, the most potent of which block the RBD-ACE2 interaction $(16,17,22-24,32-37)$. Neutralizing against other region of the viral spike have also been identified $(24,33,38-42)$. 
medRxiv preprint doi: https://doi.org/10.1101/2021.02.05.21251182; this version posted March 10, 2021. The copyright holder for this preprint (which was not certified by peer review) is the author/funder, who has granted medRxiv a license to display the preprint in perpetuity.

It is made available under a CC-BY-NC-ND 4.0 International license .

Two mRNA-based vaccines (Pfizer/BioNTech BNT162b2, and Moderna mRNA-1273) have received emergency use authorization in several countries. Both encode a stabilized ectodomain version of the S protein derived from the Wuhan-Hu-1 variant isolated in December 2019 (43), show greater than 94\% efficacy at preventing COVID-19 illness (44-47), and elicit nAbs $(48,49)$.

Due to the high global burden of SARS-CoV-2 transmission, viral evolution is occurring. Recently, viral variants of concern have emerged in the United Kingdom (B.1.1.7), South Africa (B.1.351), and Brazil (P.1) that harbor specific mutations in their S proteins that may be associated with increased transmissibility (50-55).

Of particular concern are mutations found in the B.1.351 lineage, which is defined by the D80A and D215G in the N-terminal domain (NTD), and the K417N, E484K, N501Y mutations in the RBD and the D614G mutation in S2 $(52,56)$. An A701V mutation in S2 is also observed at high frequencies, while deletions in 242-244 and a R246I mutation in the NTD and a mutation in the leader peptide $(\mathrm{L} 18 \mathrm{~F})$ are present at lower frequencies $(52)$.

The B.1.1.7, B.1.351, and P.1 lineages all harbor a N501 Y mutation in the RBD which increases the affinity for the ACE2 receptor $(57,58)$, and a D614G mutation which increases virion spike density, infectivity and transmissibility $(59,60)$. The B.1.351 and P.1 lineages also share the E484K mutations in the RBD and both variants are mutated at 417 (K417T in P.1).

Mutations found in emergent $\mathrm{S}$ variants decrease sensitivity to neutralization by mAbs, convalescent plasma, and sera from vaccinated individuals $(27,37,58,61-70)$. As a result, there is concern that these and other emerging variants can evade neutralizing antibody responses generated during infection with variants circulating earlier in the pandemic and also from 
medRxiv preprint doi: https://doi.org/10.1101/2021.02.05.21251182; this version posted March 10, 2021. The copyright holder for this preprint (which was not certified by peer review) is the author/funder, who has granted medRxiv a license to display the preprint in perpetuity.

It is made available under a CC-BY-NC-ND 4.0 International license .

neutralizing antibody responses elicited by vaccines based on the spike protein of the WuhanHu-1 variant. Indeed, there is concern that these mutations are responsible for reduced efficacy observed in ongoing trials of SARS-CoV-2 vaccines in South Africa $(71,72)$.

Here, we evaluated the neutralization susceptibility of spike variants harboring lineagedefining and prevalent B.1.351 mutations to sera from 15 donors with previously confirmed SARS-CoV-2 infection (herein referred to as previously infected donors or PIDs), that were collected prior to, and following one or two immunizations with either mRNA vaccine, or from 13 uninfected donors who received two doses of the above vaccines (herein called naïve donors or NDs; Tables S1 and S2), as well as anti-spike mAbs isolated from infected but not vaccinated patients.

Antibody neutralization experiments were performed with pseudoviruses expressing either the full-length Wuhan-Hu-1 S, or either of two versions of the B.1.351 lineage S, one herein referred to as B.1.351 containing the lineage-defining S mutations D80A, D215G, K417N, E484K, N501Y and D614G mutations and the A701V mutation that is highly prevalent in this lineage, and a second variant that also includes a $\Delta 242-243$ deletion (B.1.351 $\Delta 242-243)$. The viral stocks were appropriately diluted to achieve comparable entry levels during the neutralization experiments (Fig. S1).

We first evaluated the neutralizing potency of several mAbs isolated from non-vaccinated patients infected early in the pandemic, which target different epitopes: three against the RBD (CV30, CV3-1 and CV2-75) and one against the NTD (CV1) (Fig. S2). CV30 is a member of the VH3-53 class of antibodies that bind to the receptor binding motif (RBM) $(22,32,73-78)$. It makes direct contact with the K417 and N501 residues in the RBM that are mutated in the B.1.351 and P.1 lineages, but unlike other known VH3-53 mAbs it does not contact E484 (78). 
medRxiv preprint doi: https://doi.org/10.1101/2021.02.05.21251182; this version posted March 10, 2021. The copyright holder for this preprint (which was not certified by peer review) is the author/funder, who has granted medRxiv a license to display the preprint in perpetuity.

It is made available under a CC-BY-NC-ND 4.0 International license .

The neutralization potency of this mAb was $~ 10$-fold weaker towards both B.1.351 variants (Fig. 1A). Similarly, the non-VH3-53 mAb CV3-1 was 3-4-fold less potent against the B.1.351 variants (Fig. 1B), while CV2-75 was modestly less effective (Fig. 1C). In contrast, the antiNTD CV1 mAb was unable to neutralize either B.1.351 variant (Fig. 1D). As expected, the control anti-EBV mAb AMMO1 was non-neutralizing (79) (Fig. 1E). Collectively, these data indicate that the B.1.351 variants tested here are more resistant to neutralization by mAbs isolated from subjects infected by viral variants from early in the pandemic. We therefore examined whether the B.1.351 variants are resistant to neutralizing antibody responses elicited by the Pfizer/BioNTech or Moderna mRNA vaccines, in PIDs and NDs.

The RBD-specific IgG, IgM and IgA binding responses to the RBD from the WuhanHu1 variant were measured before (average, 202 days post symptom onset; Table S1), and 5-29 days (Table S1) after the first and second immunizations in the PIDs, and 6-28 days after the second immunization in the NDs. Three PIDs experienced asymptomatic SARS-CoV-2 infection (donors D, L, and M; Table S1) two of whom, L and M, did not have detectable anti-RBD IgG antibodies prior to immunization, while the third, D, had low but detectable serum anti-RBD IgG antibody titers (Fig. 2A). In the 13 PIDs with RBD-specific IgG antibodies prior to vaccination, a single dose of either vaccine boosted these titers by $~ 500$-fold (Fig. 2A). Across all PIDs there was a 200-fold increase in median RBD-specific IgA titers post-vaccination (Fig. 2B). Overall, in PIDs, a single vaccine dose elicited 4.5-fold higher IgG, and 7.7-fold higher IgA titers than two vaccinations in NDs. RBD-specific IgM titers were generally lower and were not significantly boosted in response to vaccination in both PIDs and NDs (Fig. 2C). In PIDs, a concomitant increase in RBD- (Fig. 2D) and S-specific $\mathrm{IgG}^{+}$(Fig. 2E) memory B cell frequencies took place after vaccination. The two PIDs that lacked RBD-specific IgG titers prior 
medRxiv preprint doi: https://doi.org/10.1101/2021.02.05.21251182; this version posted March 10, 2021. The copyright holder for this preprint (which was not certified by peer review) is the author/funder, who has granted medRxiv a license to display the preprint in perpetuity.

It is made available under a CC-BY-NC-ND 4.0 International license .

to immunization (donors $\mathrm{L}$ and $\mathrm{M}$ ) also lacked RBD-specific IgG+ memory B cells (Fig. 2D) and had lower frequencies of S-specific $\mathrm{IgG}^{+}$memory B cells after vaccination. Consistent with the serology data, an increase in the frequency of $\operatorname{Ig} \mathrm{A}^{+}$(Fig. $2 \mathrm{~F}$ ) but not $\operatorname{IgM}^{+}$spike-specific memory B cells was observed (Fig. S3). Vaccination also induced S-specific CD4 ${ }^{+}$T-cell responses (Fig. 2G).

Sera from 12 of 15 PIDs sampled before vaccination neutralized the Wuhan-Hu-1 SARSCoV-2 variant (Fig. 3A and S4). The non-neutralizing sera were from the three asymptomatic PIDs who had low or undetectable anti-RBD IgG titers (Fig. 3A dashed lines and Fig. S4), while pre-vaccine sera from the NDs were also non-neutralizing (Fig. S5). Consistent with the observed increase in binding antibodies following a single immunization in PIDs with preexisting RBD-specific IgG titers, the median half-maximal neutralizing titers ( ID $\left._{50}\right)$ were boosted approximately 1000-fold after the first dose, while the second dose had no effect (Fig. 3A). In the two PIDs lacking RBD-specific IgG titers prior to vaccination, the first vaccine dose elicited lower neutralizing titers $\left(\mathrm{ID}_{50}=\sim 100\right.$ in donor $\mathrm{L}$ and $\sim 1,100$ in donor M; Fig. 3A). In the NDs, two doses of the vaccine elicited $\mathrm{ID}_{50}$ titers that were $\sim 10$ - and 5-fold lower than those elicited by one or two doses in the PIDs, respectively (Fig. 3A and S6). Collectively, these data indicate that in PIDs who generate adequate immunological memory to the RBD, a single vaccine dose elicits an anamnestic response resulting in RBD-binding and neutralizing antibody responses that are superior to a two-dose regimen in uninfected donors.

We next evaluated the ability of sera collected before and after immunization in NDs and PIDs to neutralize the more resistant B.1.351 and B.1.351- $\Delta 242-243$ pseudoviruses. These variants are $0.5 \%$ and $0.7 \%$ divergent from the Wuhan-Hu-1 variant. We also included SARSCoV-1 pseudoviruses in this analysis, as a representative variant that is even more dissimilar to 
medRxiv preprint doi: https://doi.org/10.1101/2021.02.05.21251182; this version posted March 10, 2021. The copyright holder for this preprint (which was not certified by peer review) is the author/funder, who has granted medRxiv a license to display the preprint in perpetuity.

It is made available under a CC-BY-NC-ND 4.0 International license .

the vaccine. SARS-CoV-1 and SARS-CoV-2 are 24\%, $26 \%$ and 50\% divergent in the overall S protein, RBD and receptor binding motif, respectively (80). As a consequence, several mAbs that potently neutralize SARS CoV-2 fail to bind SARS-CoV-1 (16, 22-24).

Prior to vaccination, 5 of 15 sera from PIDs neutralized B.1.351 and only three had $\mathrm{ID}_{50}$ titers above 100 (Figs. 3B and E and S4), 7 of 15 neutralized B.1.351 $\Delta 242-243$, and only one had titers above 100 (Fig. 3C and E and S4). Only two pre-vaccine PID sera achieved 80\% neutralization of B.1.351, and only one achieved 80\% neutralization of B.1.351- $\Delta 242-243$ (Fig. S7A). The median $\mathrm{ID}_{50}$ of the pre-vaccine sera against Wuhan Hu-1 was significantly higher than against B.1.351 or B.1.351- $\Delta 242-243$ (Fig. 3E). Consistent with the high level of sequence disparity, sera from only one PID showed very weak neutralizing activity towards SARS-CoV-1 prior to vaccination (Fig. 3D and E and S7).

A single immunization boosted the nAb titers against all three SARS-CoV-2 variants and SARS-CoV-1 in 13 of 15 PIDs (Fig. 3 A-D); however, the median ID $_{50}$ titers were $~ 3$-fold lower against B.1.351, 10-fold lower against B.1.351- $\Delta 242-243$, and 100-fold lower against SARSCoV-1 than Wuhan-Hu-1 (Fig. 3E). A single immunization did not elicit nAbs against the B.1.351 variants or SARS CoV-1 in the two asymptomatic donors who lacked RBD-specific IgG memory (donor L and M; Fig. 3 A-D, and Fig. 3E open circles). The median $\mathrm{ID}_{80}$ values were also lower for the B.1.351 and B.1.351- $\triangle 242-243$ as compared to Wuhan-Hu-1 (Fig. S7A).

The neutralizing titers elicited by a single immunization in PIDs were significantly higher than those elicited by two immunizations in NDs against all pseudoviruses tested; 10-fold higher against Wuhan-Hu-1 (Fig. 3A), 20-fold higher against B.1.351 (Fig. 3B), 30-fold higher against B.1.351- $\triangle 242-243$ (Fig. 3C), and 7-fold higher against SARS-CoV-1 (Fig. 3D). Only 8 of 13 
medRxiv preprint doi: https://doi.org/10.1101/2021.02.05.21251182; this version posted March 10, 2021. The copyright holder for this preprint (which was not certified by peer review) is the author/funder, who has granted medRxiv a license to display the preprint in perpetuity.

It is made available under a CC-BY-NC-ND 4.0 International license .

vaccinated NDs were able to achieve $80 \%$ neutralization of B.1.351- $\Delta 242-243$, and none could achieve $80 \%$ neutralization of SARS-CoV-1 (Fig. S7B).

The B.1.351 and B.1.351- $\Delta 242-243$ variants contain three RBD mutations that affect the neutralization potency of anti-RBD mAbs (Fig. 1). Moreover, pre-existing anti-RBD IgG memory appears to be important for a robust recall response to vaccination. To determine the relative contribution of anti-RBD antibodies to serum neutralization, we depleted RBD-specific antibodies from the sera of ten PIDs following one vaccination and from nine NDs after two vaccinations. This approach efficiently removed RBD-specific (Fig. 4A and C) but not anti-S2P specific antibodies from sera, as measured by ELISA (Fig. B and D). This depletion abrogated serum neutralization of Wuhan-Hu-1 virus (Fig. 4C and F), and B.1.351, B.1.351- $\Delta 242-243$, or SARS-CoV-1 (not shown), suggesting that the majority of neutralizing antibodies elicited or boosted by vaccination target this subdomain.

The above results indicate that in NDs, two doses of either the Pfizer/BioNTech or Moderna vaccines elicited nAb titers against the vaccine matched Wuhan-Hu-1, lower titers against B.1.351 and even lower titers against B.1.351- $\Delta 242-243$. Reduced sensitivity to vaccineelicited nAbs has been reported for other B.1.351 variants $(66,81,82)$.

Similarly, sera from PIDs who experienced symptomatic SARS-CoV-2 infection and who had detectable anti-RBD IgG titers prior to vaccination displayed generally weak nAb titers against Wuhan-Hu-1 at one to nine months post-infection and lower, or non-existent titers against the B.1.351 variants, in agreement with another report (69) . However, provided RBDspecific $\mathrm{IgG}^{+}$memory B-cell and antibody responses were generated during infection, a single immunization with either mRNA vaccine elicited a robust recall response that boosted the autologous neutralizing titers by approximately 1000-fold and importantly, these antibody 
medRxiv preprint doi: https://doi.org/10.1101/2021.02.05.21251182; this version posted March 10, 2021. The copyright holder for this preprint (which was not certified by peer review) is the author/funder, who has granted medRxiv a license to display the preprint in perpetuity.

It is made available under a CC-BY-NC-ND 4.0 International license .

responses cross-neutralized the B.1.351 variants, but at lower titers. In the majority of previously infected vaccinees, the anti- B.1.351- $\Delta 242-243$ neutralizing titers were comparable to those against the vaccine-matched Wuhan-Hu-1 in uninfected vaccinees. This is notable as these titers were associated with $95 \%$ protection from COVID-19 in phase 3 trials $(44,46,48,49)$. Moreover, vaccine-elicited antibody responses also neutralized SARS-CoV-1, but with much lower potencies. Collectively, our data suggest that the two mRNA vaccines that are based on the Wuhan-Hu-1 variant can elicit and/or boost neutralizing antibody responses, but that their potency is reduced against divergent variants.

Here, we show that the cross-neutralizing antibody responses generated after immunization in previously infected subjects are due to anti-RBD antibodies. Combined with the observation that the vaccines elicited neutralizing antibody responses that are less potent against the B.1.351 variant with the 242-243 deletion in the NTD suggests that NTD mutations can modulate the sensitivity of emerging variants to anti-RBD neutralizing antibodies. In contrast, the NTD region itself, which appears to tolerate antigenic variation in SARS-CoV-2 and other coronaviruses (50, $52,55,83)$, does not appear to be the target of cross-neutralizing antibodies elicited by infection or vaccination. We note that there are other less-frequent mutations associated with this lineage, such as L18F, $\triangle 244, \mathrm{~L} 244 \mathrm{H}$, and R246I that were not examined here which may further increase resistance to vaccine-elicited antibodies.

Although the correlates of protection for SARS CoV-2 vaccines have not been established, studies in non-human primates indicate that even low titers of neutralizing antibodies are sufficient to prevent experimental SARS-CoV-2 infection, particularly if CD8+ Tcell responses are mounted (18). Our study suggests that most previously infected subjects will benefit from a single immunization with either the Pfizer/BioNTech or Moderna vaccines as it 
will lead to significant increases in serum neutralizing antibody responses against vaccinematched and emerging variants. The observation that a second dose administered three to four weeks following the first in previously infected donors who have clear evidence of RBD-directed immunological memory prior to vaccination did not further boost neutralizing titers, suggests that the second dose of an mRNA vaccine could be delayed in some persons who have previously been infected with SARS-CoV-2. Longitudinal monitoring of the neutralizing antibody titers before and following the first dose should be used to determine the necessity, or optimal timing of the second dose in the context of previous infection. 


\section{FIGURES}

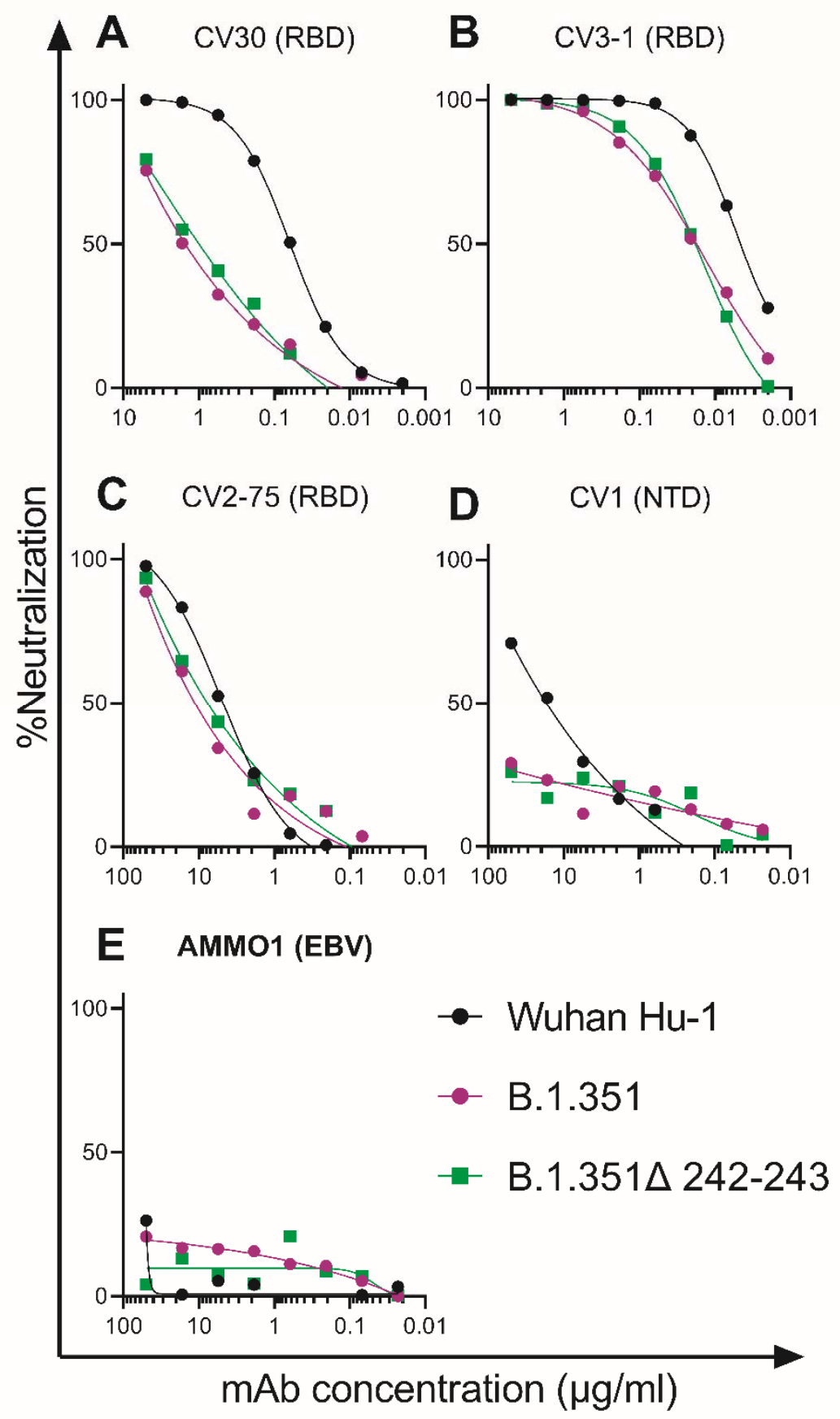

Figure 1. B.1.351 variants show decreased susceptibility to neutralizing monoclonal anibodies. The ability of the indicated monoclonal antibodies (mAbs) to neutralize Wuhan-Hu1, B.1.351 and B.1.351 $\Delta 242-243$ pseudovirus infectivity in 293T-hACE2 cells was measured as indicated. The epitope specificity of each $\mathrm{mAb}$ is shown in parentheses (RBD: receptor binding domain; NTD: N-terminal domain; EBV: Epstein-Barr virus). Data points represent the mean of two techincal replicates. Data is represenative of two independent experiments. 

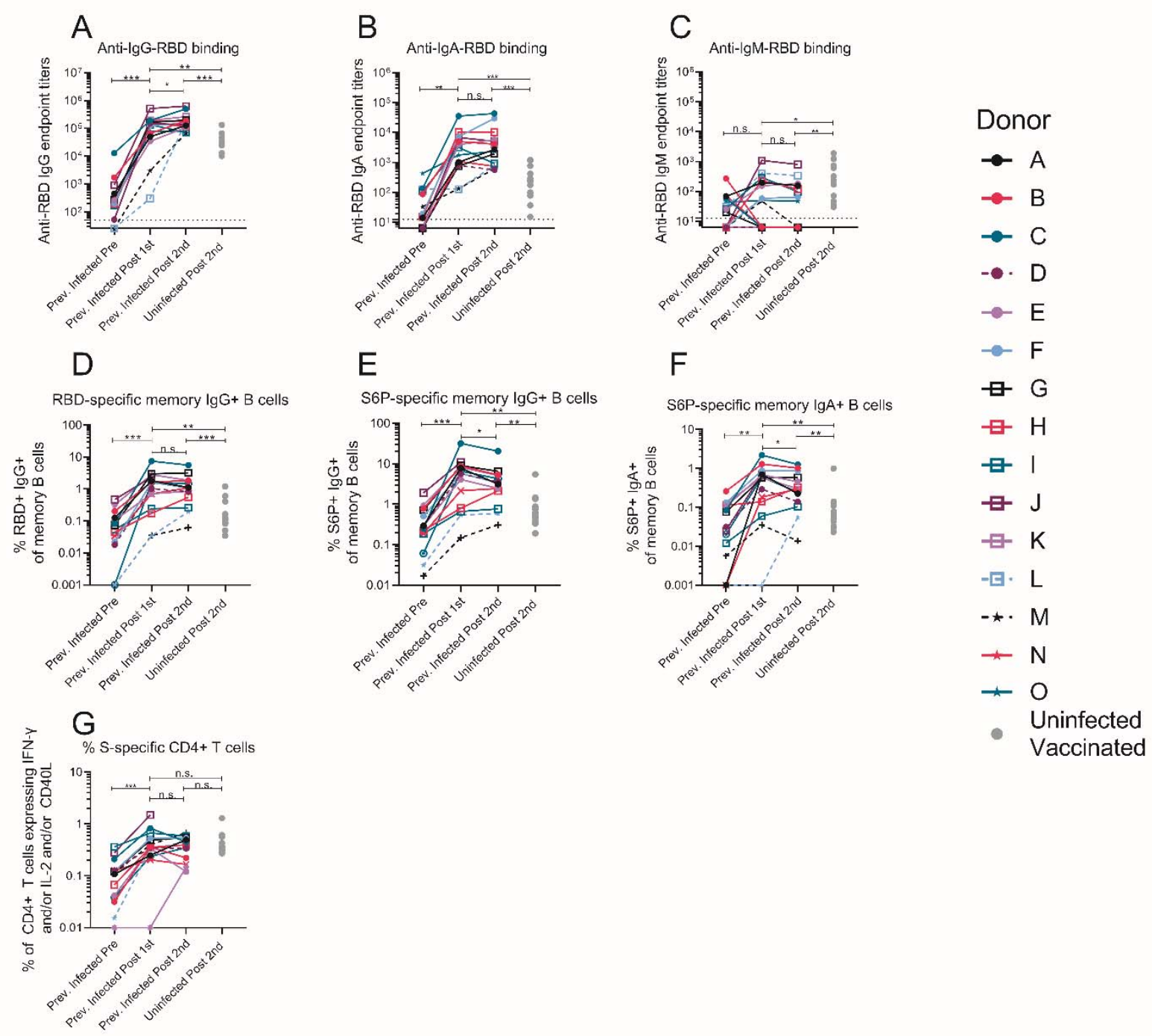

Figure 2. A single dose of a spike-derived mRNA vaccine elicits a strong recall response. $\operatorname{IgG}(\mathbf{A}), \operatorname{Ig} \mathrm{A}(\mathbf{B})$ and $\operatorname{IgM}(\mathbf{C})$ end-point antibody titers specific to the receptor binding domain of the Wuhan-Hu-1 variant were measured in serum collected from donors previously infected with SARS-CoV-2 before and after one or two immunizations with the Pfizer/BioNTech or Moderna mRNA vaccines by ELISA, as indicated. Endpoint titers measured in sera from uninfected donors following two vaccine doses are shown for comparison (gray dots). (D) Frequency of Wuhan-Hu-1 RBD-specific IgG+ memory B cells (live, IgD ${ }^{-}, \mathrm{CD}_{1}{ }^{+}, \mathrm{CD} 20^{+}$, $\mathrm{CD}^{-}, \mathrm{CD} 14, \mathrm{CD} 56^{-}$, singlet, lymphocytes) in PBMC from previously infected donors was measured before and after one or two immunizations. The frequency of S6P-specific $\operatorname{IgG}^{+}(\mathbf{E})$ and $\operatorname{Ig} \mathrm{A}^{+}(\mathbf{F})$ memory B cells in PBMC previously infected donors were measured before and after one or two immunizations. The frequency of memory B cells from uninfected donors following two vaccine doses are shown for comparison in D-F (gray dots). (G) The frequency of S-specific CD4+ T cells expressing IFN- $\gamma$ and/or IL-2 and/or CD40L in PBMC from previously infected donors was measured before and after one or two immunizations. The frequency of Sspecific CD4+ T cells in PBMC from uninfected donors following two vaccine doses are shown for comparison (gray dots). Experiments were performed once. Significant differences in 
medRxiv preprint doi: https://doi.org/10.1101/2021.02.05.21251182; this version posted March 10, 2021. The copyright holder for this preprint (which was not certified by peer review) is the author/funder, who has granted medRxiv a license to display the preprint in perpetuity. It is made available under a CC-BY-NC-ND 4.0 International license .

infected donors before or after vaccination (A-D) or between pseudoviruses $(\mathbf{E})$ were determined using a Wilcoxon signed rank test $(* \mathrm{p}<0.05, * * \mathrm{p}<0.01$ and $* * * \mathrm{p}<0.001)$. Significant differences between previously infected and uninfected donors (A-D) were determined using a Wilcoxon rank sum test $(* \mathrm{p}<0.05, * * \mathrm{p}<0.01$ and $* * \mathrm{p}<0.001)$. 
medRxiv preprint doi: https://doi.org/10.1101/2021.02.05.21251182; this version posted March 10, 2021. The copyright holder for this preprint (which was not certified by peer review) is the author/funder, who has granted medRxiv a license to display the preprint in perpetuity.

It is made available under a CC-BY-NC-ND 4.0 International license .

A

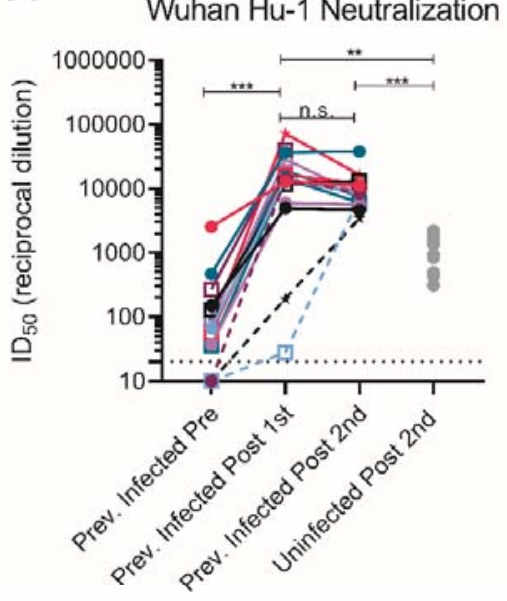

C

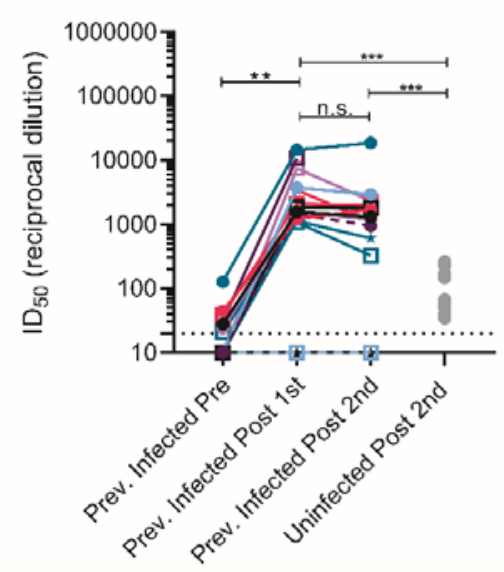

E

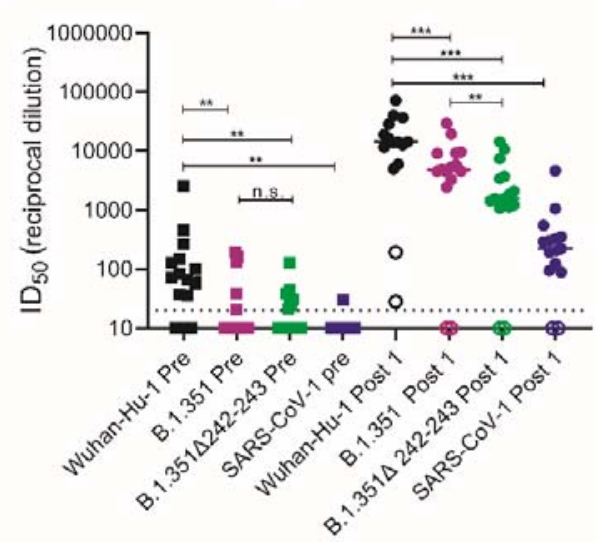

B

B.1.531 Neutralization

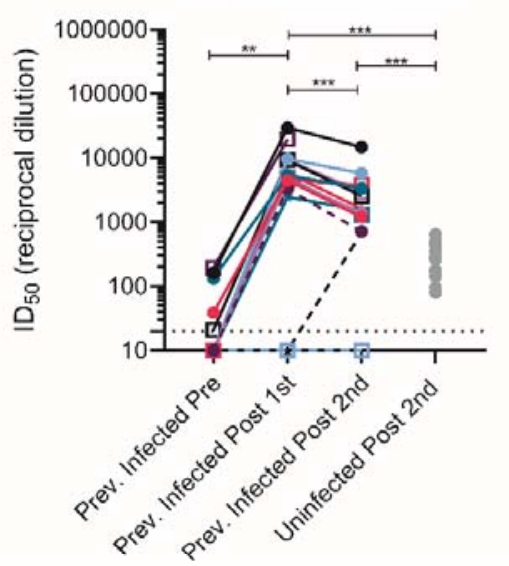

D SARS-CoV-1 Neutralization

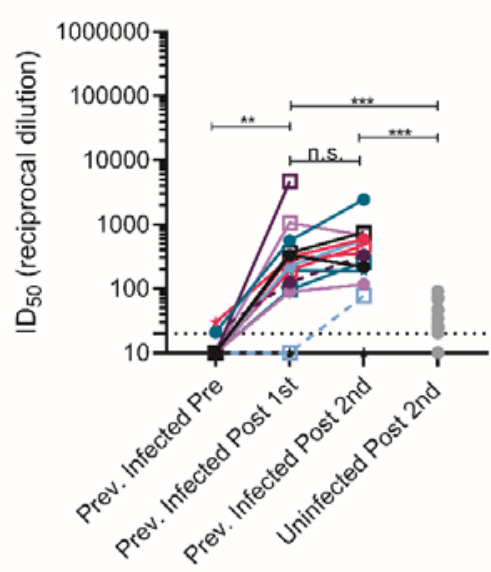

$\mathbf{F}$

Uninfected Vaccinated

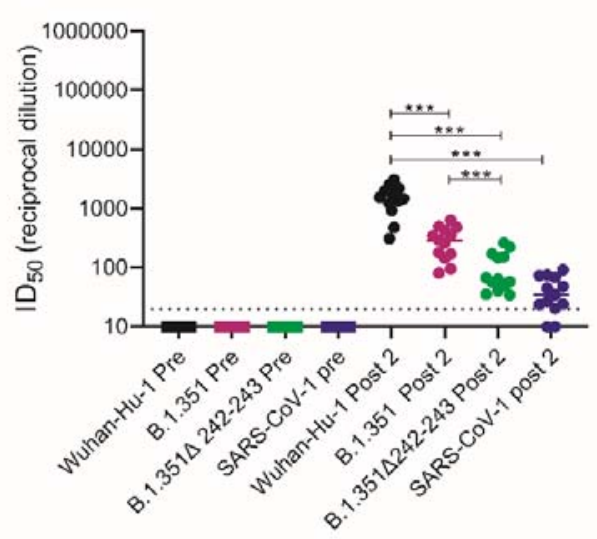

Figure 3. Pre-existing SARS-CoV-2 neutralizing antibody responses are boosted by a single dose of a spike-derived mRNA vaccine. The serum dilution resulting in $50 \%$ neutralization 
medRxiv preprint doi: https://doi.org/10.1101/2021.02.05.21251182; this version posted March 10, 2021. The copyright holder for this preprint (which was not certified by peer review) is the author/funder, who has granted medRxiv a license to display the preprint in perpetuity.

It is made available under a CC-BY-NC-ND 4.0 International license .

$\left(\right.$ ID $\left._{50}\right)$ of (A) Wuhan-Hu-1, (B) B.1.351, (C) B.1.351 $4242-243$, and (D) SARS-CoV-1 pseudoviruses was measured in recovered COVID-19 donors prior to and following a one or two immunizations with the Pfizer/BioNTech or Moderna vaccines, and in uninfected donors following two vaccine doses as indicated. Data points between previously infected donors who were symptomatic and asymptomatic are connected by solid and dashed lines, respectively in AD. (E) Serum dilution resulting in $50 \%$ neutralization $\left(\mathrm{ID}_{50}\right)$ from recovered donors prior to (squares) and following a single immunization (circles) with the Pfizer/BioNTech or Moderna vaccines against Wuhan-Hu-1, B.1.351, B.1.351 $\triangle 242-243$ and SARS-CoV-1 pseudoviruses as indicated. Previoulsy infected donors who were asymptomatic, negative for anti-IgG RBD antibodies, and RBD-specific IgG+ memory B cells prior to vaccination are shown as open circles. (F) Neutralizing potency $\left(\mathrm{ID}_{50}\right)$ of serum from uninfected donors following two immunizations with the Pfizer/BioNTech or Moderna vaccines against the indicated pseudoviruses. Each data point represents a different donor and the horizonal bars represent the medians in $\mathbf{E}$ and $\mathbf{F}$. The dashed lines demarcate the lowest serum dilutions tested. Experiments were performed once. Significant differences in infected donors before or after vaccination, or from the same timepoint against different variants $(* \mathrm{p}<0.05, * * \mathrm{p}<0.01$ and $* * * \mathrm{p}<0.001)$ were determined using a Wilcoxon signed rank test. Significant differences between previously infected and uninfected donors $(* \mathrm{p}<0.05, * * \mathrm{p}<0.01$ and $* * * \mathrm{p}<0.001)$ were determiend using a Wilcoxon rank sum test. 

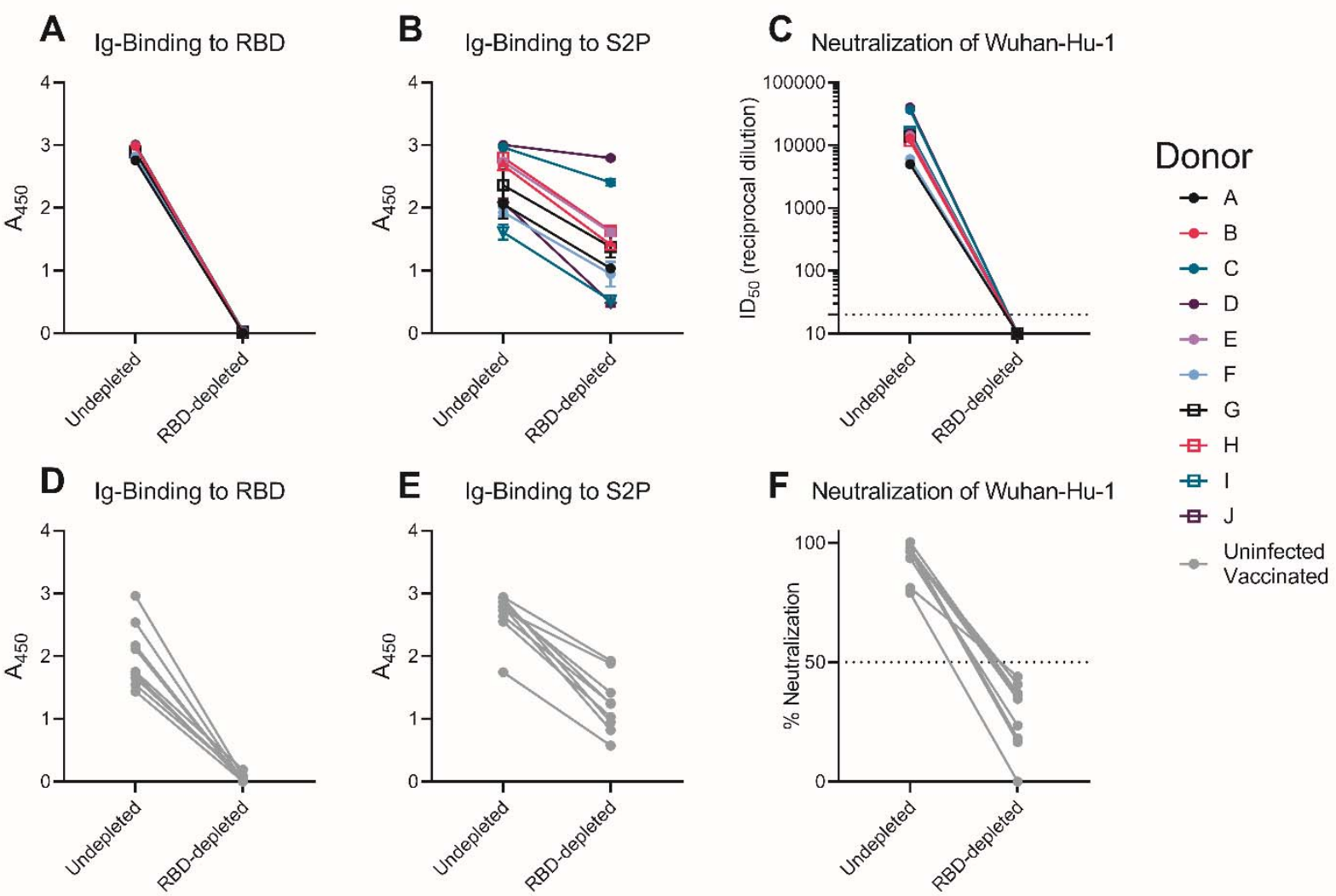

Figure 4. Vaccine-elicited neutralizing antibodies target the RBD.

RBD-binding antibodies were adsorbed from sera from previously infected donors after receiving a single vaccine dose, or from uninfected donors after receiving two vaccine doses using Wuhan-Hu-1 RBD immobilized to magnetic beads. Antibody binding in undepleted or RBD-depleted serum from previously infected donors was measured to RBD at a 1:500 dilution (A), and S2P at a 1:4500 dilution (B) by ELISA as indicated. (C) The serum dilution resulting in $50 \%$ neutralization $\left(\mathrm{ID}_{50}\right.$ ) of the Wuhan-Hu-1 pseudovirus was measured in undepleted or RBDdepleted of serum from the previously SARS-CoV-2 infected donors in A and $\mathbf{B}$. Antibody binding in undepleted and RBD-depleted and sera from uninfected vaccinated donors was measured to RBD at a 1:500 dilution (D), and S2P at a 1:500 dilution (E) by ELISA. (F) The percent neutralization of a 1:120 dilution of undepleted or RBD-depleted of serum from the donors in D and E was measured against the Wuhan-Hu-1 pseudovirus. Experiments were performed once. 
medRxiv preprint doi: https://doi.org/10.1101/2021.02.05.21251182; this version posted March 10, 2021. The copyright holder for this preprint (which was not certified by peer review) is the author/funder, who has granted medRxiv a license to display the preprint in perpetuity.

It is made available under a CC-BY-NC-ND 4.0 International license .

\section{Materials and Methods}

\section{$\underline{\text { Human Subjects }}$}

Peripheral blood mononuclear cells (PBMCs) and serum were collected from participants enrolled in the longitudinal study, "Seattle COVID-19 Cohort Study to Evaluate Immune Responses in Persons at Risk and with SARS-CoV-2 Infection". Eligibility criteria included adults in the greater Seattle area at risk for SARS-CoV2 infection or those diagnosed with COVID-19 by a SARS CoV-2 PCR assay University of Washington multiplex PCR reaction using CDC approved primers/probes for the virus nucleocapsid (N) gene, N1 and N2) or blood antibody test (SARS CoV-2 IgG Architect, Abbot). Fifteen participants who recovered from SARS-CoV-2 and 13 that were SARS-CoV2 negative were selected from among those that were the first to receive two doses of an Emergency Use Authorization COVID-19 vaccine. Samples were selected based on availability. Sample sizes, randomization, or blinding were not predetermined, nor were there specific inclusion/exclusion criteria. Serum or plasma from prepandemic controls were blindly selected at random from the study, "Establishing Immunologic Assays for Determining HIV-1 Prevention and Control", with no considerations made for age, or sex. Both studies were recruited at the Seattle Vaccine Trials Unit (Seattle, Washington, USA). Informed consent was obtained from all participants and the Fred Hutchinson Cancer Research Center Institutional Review Board approved the studies and procedures (IR10440 and IR5567). Study data were collected and managed using REDCap electronic data capture tools hosted at Fred Hutchinson Cancer Research Center $(84,85)$.

\section{$\underline{\text { Cell Lines }}$}


medRxiv preprint doi: https://doi.org/10.1101/2021.02.05.21251182; this version posted March 10, 2021. The copyright holder for this preprint (which was not certified by peer review) is the author/funder, who has granted medRxiv a license to display the preprint in perpetuity.

It is made available under a CC-BY-NC-ND 4.0 International license .

All cell lines were incubated at $37^{\circ} \mathrm{C}$ in the presence of 5\% $\mathrm{CO} 2.293-6 \mathrm{E}$ (human female, RRID:CVCL_HF20) and 293T cells (human female, RRID:CVCL_0063) cells were maintained in Freestyle 293 media with gentle shaking. HEK-293T-hACE2 (human female, BEI Resources Cat\# NR-52511) were maintained in DMEM containing 10\% FBS, 2 mM L-glutamine, 100 U/ml penicillin, and $100 \mu \mathrm{g} / \mathrm{ml}$ streptomycin (cDMEM).

$\underline{\text { Recombinant }} \underline{\mathrm{CoV}}$ proteins $\underline{\text { and }} \underline{\mathrm{mAbs}}$

A stabilized version of the recombinant SARS-CoV-2 spike protein (S2P) and the SARS CoV-2 RBD were produced in 293E cells as previously described $(8,22)$. Recombinant CV1, CV30 and AMMO1 were expressed in 293 cells and purified using protein A resin as previously described $(22,79)$. CV3-1 (Genbank: variable heavy region-MW681558, variable light region MW681586), and CV2-75 (Genbank: variable heavy region-MW681758, variable light region MW68175) mAbs were isolated from donors previously infected with SARS-CoV-2 using recombinant S2P as bait between 3.5 and 6 weeks post symptom-development, using methods outlined in (22).

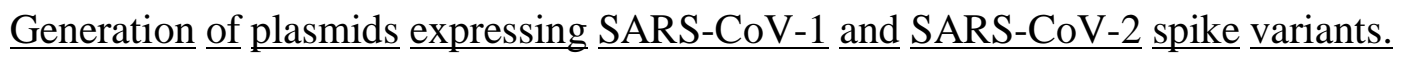

To generate a plasmid encoding the SARS-CoV-2 spike B.1.351 variant (pHDM-SARSCoV-2-Spike- B.1.351) we designed primers that anneal 5' of the D80 codon and just 3' of the A701 codon on the pHDM-SARS-CoV-2 Spike Wuhan-Hu-1 plasmid (BEI Resources Cat\# NR52514) that were used to amplify cDNA corresponding to the $\mathrm{N}$ and $\mathrm{C}$ termini of the spike protein and the plasmid backbone using Platinum SuperFi II DNA Polymerase (Thermofisher Cat\# 12368010) according to the manufacturer's instructions. cDNA encoding the rest of the 
medRxiv preprint doi: https://doi.org/10.1101/2021.02.05.21251182; this version posted March 10, 2021. The copyright holder for this preprint (which was not certified by peer review) is the author/funder, who has granted medRxiv a license to display the preprint in perpetuity.

It is made available under a CC-BY-NC-ND 4.0 International license .

spike protein including the D80A, D215G, K417N, E484K, N501Y, D614G and A701V mutations was synthesized as two g blocks (Integrated DNA technologies). The first had 30nt of homology with the PCR amplified vector backbone at the 5' end. The second included and 30nt of homology with the 3' end of the first block at the 5' end and 30nt of homology with the PCR amplified vector backbone at the 3' end. The g blocks and PCR product were ligated together using InFusion HD cloning Plus (TakaraBio Cat\#638920). pHDM-SARS-CoV-2-SpikeB.1.351 $\Delta 242-243$ was generated by deleting the amino acids 242-243 in pHDM-SARS-CoV-2Spike- B.1.351 using site directed mutagenesis.

To generate a plasmid encoding the SARS-CoV-2 spike, codon-optimized cDNA corresponding to the SARS-CoV S protein (Urbani, GenBank: AAP13441.1) flanked on the 5' end by 30nt of homology upstream of and including the EcoRI site, and flanked on the 3' end by 30nt of homology downstream of and including the HindIII site on the pHDM-SARS-CoV-2 Spike Wuhan-Hu-1 plasmid was synthesized by Twist Biosciences. The synthesized DNA was cloned into the pHDM-SARS-CoV-2 Spike Wuhan-Hu-1 plasmid that was cut with EcoRI and HindIII and gel purified to remove the SARS-CoV-2 Spike cDNA using InFusion HD cloning Plus. The sequences of the cDNA in pHDM-SARS-CoV-Spike-B.1.351 and pHDM-SARS-CoV Spike were verified by Sanger sequencing (Genewiz Inc.).

\section{$\underline{\text { Pseudovirus }} \underline{\text { neutralization assay }}$}

HIV-1 derived viral particles were pseudotyped with full length wildtype S from Wuhan Hu1, B.1.351, B.1.351 $\triangle 242-243$, or SARS CoV-1 using a previously described reporter system (86), Briefly, plasmids expressing the HIV-1 Gag and pol (pHDM540 Hgpm2, BEI Resources Cat\# NR-52517), HIV-1Rev (pRC-CMV-rev1b, BEI Resources Cat\# NR-52519), HIV-1 Tat 
medRxiv preprint doi: https://doi.org/10.1101/2021.02.05.21251182; this version posted March 10, 2021. The copyright holder for this preprint (which was not certified by peer review) is the author/funder, who has granted medRxiv a license to display the preprint in perpetuity.

It is made available under a CC-BY-NC-ND 4.0 International license .

(pHDM-tat1b, BEI resources NR-52518), the SARS-CoV-2 spike (pHDM-SARS-CoV-2 Spike

Wuhan-Hu-1, pHDM-SARS-CoV-2 Spike B.1.351, or pHDM-SARS-CoV-1 Spike) and a luciferase/GFP reporter (pHAGE-CMV-Luc2-IRES542 ZsGreen-W, BEI Resources Cat\# NR52516) were co-transfected into $293 \mathrm{~T}$ cells at a 1:1:1:1.6:4.6 ratio using 293 Free transfection reagent according to the manufacturer's instructions. Pseudoviruses lacking a spike protein were also produced as a control for specific viral entry. Pseudoviron production was carried out at 32 ${ }^{\circ} \mathrm{C}$ for 72 hours after which the culture supernatant was harvested, clarified by centrifugation and frozen at $-80^{\circ} \mathrm{C}$.

293 cells stably expressing human HEK-293T-hACE2 were seeded at a density of 4x10 3 cells/well in a $100 \mu \mathrm{L}$ volume in 96 well flat bottom black-walled, clear bottom tissue culture plates (Greiner CELLSTAR Cat\#655090). The next day, mAbs or sera were serially diluted in 70 $\mu \mathrm{L}$ of cDMEM in 96 well round bottom master plates in duplicate wells. $30 \mu \mathrm{L}$ of serially diluted mAbs or sera from the master plate were replica plated into 96 well round bottom plates. An equal volume of viral supernatant diluted to achieve comparable luciferase values between SARS-CoV-2 variants (Fig S1) was added to 96 well round bottom plates containing identical serial dilutions from the same master plate, and incubated for $60 \mathrm{~min}$ at $37^{\circ} \mathrm{C}$. Meanwhile $50 \mu \mathrm{L}$ of cDMEM containing $6 \mu \mathrm{g} / \mathrm{mL}$ polybrene was added to each well of 293T-ACE2 cells (2 $\mu \mathrm{g} / \mathrm{mL}$ final concentration) and incubated for $30 \mathrm{~min}$. The media was aspirated from 293T-ACE2 cells and $100 \mu \mathrm{L}$ of the virus-antibody mixture was added. The plates were incubated at $37^{\circ} \mathrm{C}$ for 72 hours. The supernatant was aspirated and replaced with $100 \mu \mathrm{L}$ of Steadyglo luciferase reagent (Promega Cat\# E2510) and read on a Fluorskan Ascent Fluorimeter. Control wells containing virus but no antibody (cells + virus) and no virus or antibody (cells only) were included on each plate. 
medRxiv preprint doi: https://doi.org/10.1101/2021.02.05.21251182; this version posted March 10, 2021. The copyright holder for this preprint (which was not certified by peer review) is the author/funder, who has granted medRxiv a license to display the preprint in perpetuity.

It is made available under a CC-BY-NC-ND 4.0 International license .

Percent neutralization for each well was calculated as the RLU of the average of the cells + virus wells, minus test wells (cells $+\mathrm{mAb} / \mathrm{sera}+$ virus), and dividing this result difference by the average RLU between virus control (cells + virus) and average RLU between wells containing cells alone, multiplied by 100 . The antibody concentration, or serum dilution that neutralized $50 \%$ or $80 \%$ of infectivity ( $\mathrm{IC}_{50}$ and $\mathrm{IC}_{80}$ for $\mathrm{mAbs}, \mathrm{ID}_{50}$ and $\mathrm{ID}_{80}$ for serum) was interpolated from the neutralization curves determined using the $\log ($ inhibitor) vs. response -- Variable slope (four parameters) fit using automatic outlier detection in Graphpad Prism Software. Serum that did not achieve 50\% neutralization at the lowest dilution tested (1:20) were considered negative and assigned an $\mathrm{ID}_{50}$ value of 10 .

\section{$\underline{\text { RBD }} \underline{\text { ELISAs }}$}

Half-well area plates (Greiner) were coated with purified RBD protein at $16.25 \mathrm{ng} /$ well in PBS (Gibco) for 14-24h at room temperature. After 4 150ul washes with 1X PBS, 0.02\% Tween2 (Sigma) using the BioTek ELx405 plate washer, the $\operatorname{IgA}$ and $\operatorname{IgG}$ plates were blocked at $37^{\circ} \mathrm{C}$ for 1-2 hours with 1X PBS, 10\% non-fat milk (Lab Scientific), 0.02\% Tween-20 (Sigma); IgM plates were blocked with $1 \mathrm{X}$ PBS, 10\% non-fat milk, 0.05\% Tween-20.

Serum samples were heat inactivated by incubating at $56^{\circ} \mathrm{C}$ for 30 minutes, then centrifuged at $10,000 \mathrm{x} \mathrm{g} / 5$ minutes, and stored at $4{ }^{\circ} \mathrm{C}$ previous to use in the assay. For IgG ELISAs, serum was diluted into blocking buffer in 7-12 1:4 serial dilutions stating at 1:50. For IgM and $\operatorname{Ig} \mathrm{A}$ ELISAs, serum was diluted into 7 1:4 serial dilutions stating at 1:12.5 to account for their lower concentration. A qualified pre-pandemic sample (negative control) and a standardized mix of seropositive serums (positive control) was run in each plate and using to define passing criteria 
medRxiv preprint doi: https://doi.org/10.1101/2021.02.05.21251182; this version posted March 10, 2021. The copyright holder for this preprint (which was not certified by peer review) is the author/funder, who has granted medRxiv a license to display the preprint in perpetuity.

It is made available under a CC-BY-NC-ND 4.0 International license .

for each plate. All controls and test serums at multiple dilutions were plated in duplicate and incubated at $37^{\circ} \mathrm{C}$ for 1 hour, followed by 4 washes in the automated washer. 8 wells in each plate did not receive any serum and served as blocking controls.

Plates then were plated with secondary antibodies (all from Jackson ImmunoResearch) diluted in blocking buffer for $1 \mathrm{~h}$ at 37C. IgG plates used donkey anti-human IgG HRP Cat \# 709035-098) diluted at 1:7500; IgM plates used goat anti-human IgM HRP (Cat\# 109-035-043) diluted at 1:10,000; IgA plates used goat anti-human IgA HRP (Cat\# 109-035-011) at 1:5000. After 4 washes, plates were developed with 25ul of SureBlock Reserve TMB Microwell Peroxide Substrate (Seracare) for $4 \mathrm{~min}$, and the reaction stopped by the addition of $50 \mu \mathrm{l} 1 \mathrm{~N}$ sulfuric acid (Fisher) to all wells. Plates were read at $\mathrm{OD}_{450 \mathrm{~nm}}$ on SpectraMax i3X ELISA plate reader within 20 min of adding the stop solution.

$\mathrm{OD}_{450 \mathrm{~nm}}$ measurements for each dilution of each sample were used to extrapolate endpoint titers when CVs were less than 20\%. Using Excel, endpoint titers were determined by calculating the point in the curve at which the dilution of the sample surpassed that of 5 times the average $\mathrm{OD}_{450 \mathrm{~nm}}$ of blocking controls +1 standard deviation of blocking controls.

\section{$\underline{\text { RBD-specific antibody depletion }}$}

SARS-CoV-2 RBD was coupled to Pierce NHS-activated magnetic beads (Thermo Fisher) at a ratio of $50 \mu \mathrm{g}$ of RBD to $1 \mathrm{mg}$ of beads according to manufacturer's instructions and stored in PBS. Plasma samples were diluted 1:50 in DMEM in a total volume of 500 $\mu 1$. Diluted plasma was incubated with of 65 ul of RBD-coupled beads. Samples were continually mixed at RT for 1 hour. Diluted sera was removed from immobilized magnetic beads using a magnetic stand and the sera were incubated with fresh beads two additional times. Depleted serum was filter 
medRxiv preprint doi: https://doi.org/10.1101/2021.02.05.21251182; this version posted March 10, 2021. The copyright holder for this preprint (which was not certified by peer review) is the author/funder, who has granted medRxiv a license to display the preprint in perpetuity.

It is made available under a CC-BY-NC-ND 4.0 International license .

sterilized using a 0.22 um spin filter. The presence of binding antibodies in depleted and undepleted sera was measured using recombinant RBD and S2P by ELISA using a polyclonal anti-IgG secondary (Southern Biotech Cat\# 2010-05)

$\underline{\text { Spike and }} \underline{\text { RBD }} \underline{\text { memory }} \underline{B} \underline{\text { cell flow }} \underline{\text { cytometry assays }}$

Fluorescent SARS-CoV-2-specific S6P (87) (provided by Roland Strong, Fred Hutchinson Cancer Research Center, Seattle, WA) and RBD probes were made by combining biotinylated protein with fluorescently labeled streptavidin. The S6P probes were made at a ratio of 1:1 molar ratio of trimer to SA. Two S6P probes, one labeled with AlexaFluor488 (Invitrogen), one labeled with AlexaFluor647 (Invitrogen), were used in this panel in order to increase specificity of the detection of SARS-CoV-2-specific B cells. The RBD probe was prepared at a 4:1 molar ratio of RBD monomers to SA, labeled with R-phycoerythrin (Invitrogen). Cryopreserved PBMCs from SARS-CoV-2-convalescent participants and a pre-pandemic SARSCoV-2-naïve donor were thawed at $37^{\circ} \mathrm{C}$ and stained for SARS-CoV-2-specific memory B cells with a flow cytometry panel shown in Supplementary Table 3. Cells were stained first with the viability stain (Invitrogen) in PBS for 15 min at $4^{\circ} \mathrm{C}$. Cells were then washed with $10 \% \mathrm{FBS} / \mathrm{PBS}$ and stained with a cocktail of the three probes for $30 \mathrm{~min}$ at $4^{\circ} \mathrm{C}$. The probe cocktail was washed off with $10 \%$ FBS/PBS and the samples were stained with the remaining antibody panel and incubated for $25 \mathrm{~min}$ at $4^{\circ} \mathrm{C}$. The cells were washed two times and resuspended in $1 \%$ paraformaldehyde/1x PBS for collection on an LSR II flow cytometer (BD Biosciences). Data was analyzed in Flow Jo version 9.9.4.

$\underline{\text { Intracellular }} \underline{\text { Cytokine }} \underline{\text { Staining }} \underline{\text { (ICS) }} \underline{\text { Assay }}$ 
medRxiv preprint doi: https://doi.org/10.1101/2021.02.05.21251182; this version posted March 10, 2021. The copyright holder for this preprint (which was not certified by peer review) is the author/funder, who has granted medRxiv a license to display the preprint in perpetuity.

It is made available under a CC-BY-NC-ND 4.0 International license .

Flow cytometry was used to examine SARS-CoV-2-specific CD4+ T-cell responses using a validated ICS assay. The assay was similar to published reports $(88,89)$ and the details of the staining panel are included in Supplemental Table 4. Two peptide pools (15 amino acids overlapping by 11 amino acids, provided by BioSynthesis) covering the spike protein of SARSCoV-2 were used for the six-hour stimulation. Peptide pools were used at a final concentration of $1 \mu \mathrm{g} / \mathrm{ml}$ for each peptide. As a negative control, cells were not stimulated, only the peptide diluent (DMSO) was included. As a positive control, cells were stimulated with a polyclonal stimulant, staphylococcal enterotoxin B (SEB). Cells expressing IFN- $\gamma$ and/or IL-2 and/or CD154 was the primary endpoint for antigen-specific $\mathrm{CD}^{+} \mathrm{T}$ cells. The overall response to spike was defined as the sum of the background-subtracted responses to the spike 1 and spike 2 individual pools. The total number of $\mathrm{CD}^{+} \mathrm{T}$ cells must have exceeded 10,000 the assay data to be included in the analysis.

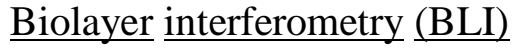

BLI experiments were performed on an Octet Red instrument at $30^{\circ} \mathrm{C}$ with shaking at 500 $1000 \mathrm{rpm}$. mAbs were loaded at a concentration of $20 \mathrm{mg} / \mathrm{mL}$ in PBS onto Anti-Human IgG Fc capture (AHC) biosensors (Fortebio) for 300s, followed by a 60s baseline in KB buffer (1X PBS, $0.01 \%$ Tween $20,0.01 \%$ BSA, and $\left.0.005 \% \mathrm{NaN}_{3}, \mathrm{pH} 7.4\right)$. Probes were then dipped in KB containing either; SARS-CoV-2 RBD $(2.0 \mu \mathrm{M}), \mathrm{S}-2 \mathrm{P}(0.5 \mu \mathrm{M}), \mathrm{S} 1 \mathrm{NTD}(0.5 \mu \mathrm{M}$, SinoBiological

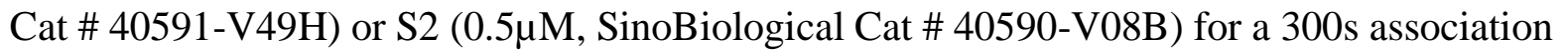
phase, followed by a 300s dissociation phase in KB. The binding of mature VRC01 (90) was used as negative control to subtract background binding at each timepoint. 


\section{REFERENCES}

1. E. Dong, H. Du, L. Gardner, An interactive web-based dashboard to track COVID-19 in real time. The Lancet infectious diseases 20, 533-534 (2020).

2. P. Zhou et al., A pneumonia outbreak associated with a new coronavirus of probable bat origin. Nature 579, 270-273 (2020).

3. N. Zhu et al., A Novel Coronavirus from Patients with Pneumonia in China, 2019. The New England journal of medicine 382, 727-733 (2020).

4. A. C. Walls et al., Structure, Function, and Antigenicity of the SARS-CoV-2 Spike Glycoprotein. Cell 181, 281-292.e286 (2020).

5. M. Hoffmann et al., SARS-CoV-2 Cell Entry Depends on ACE2 and TMPRSS2 and Is Blocked by a Clinically Proven Protease Inhibitor. Cell 181, 271-280.e278 (2020).

6. M. Letko, A. Marzi, V. Munster, Functional assessment of cell entry and receptor usage for SARS-CoV-2 and other lineage B betacoronaviruses. Nat Microbiol 5, 562-569 (2020).

7. X. Ou et al., Characterization of spike glycoprotein of SARS-CoV-2 on virus entry and its immune cross-reactivity with SARS-CoV. Nature communications 11, 1620 (2020).

8. D. Wrapp et al., Cryo-EM structure of the 2019-nCoV spike in the prefusion conformation. Science 367, 1260-1263 (2020).

9. A. Addetia et al., Neutralizing Antibodies Correlate with Protection from SARS-CoV-2 in Humans during a Fishery Vessel Outbreak with a High Attack Rate. Journal of clinical microbiology 58, (2020).

10. I. W. Pray et al., COVID-19 Outbreak at an Overnight Summer School Retreat - Wisconsin, JulyAugust 2020. MMWR. Morbidity and mortality weekly report 69, 1600-1604 (2020).

11. S. F. Lumley et al., Antibody Status and Incidence of SARS-CoV-2 Infection in Health Care Workers. The New England journal of medicine 384, 533-540 (2021).

12. A. Chandrashekar et al., SARS-CoV-2 infection protects against rechallenge in rhesus macaques. Science 369, 812-817 (2020).

13. W. Deng et al., Primary exposure to SARS-CoV-2 protects against reinfection in rhesus macaques. Science 369, 818-823 (2020).

14. D. S. Stephens, M. J. McElrath, COVID-19 and the Path to Immunity. JAMA : the journal of the American Medical Association 324, 1279-1281 (2020).

15. K. P. O'Callaghan, A. M. Blatz, P. A. Offit, Developing a SARS-CoV-2 Vaccine at Warp Speed. JAMA : the journal of the American Medical Association 324, 437-438 (2020).

16. T. F. Rogers et al., Isolation of potent SARS-CoV-2 neutralizing antibodies and protection from disease in a small animal model. Science 369, 956-963 (2020).

17. S. J. Zost et al., Potently neutralizing and protective human antibodies against SARS-CoV-2. Nature 584, 443-449 (2020).

18. K. McMahan et al., Correlates of protection against SARS-CoV-2 in rhesus macaques. Nature 590, 630-634 (2020).

19. A. Baum et al., REGN-COV2 antibodies prevent and treat SARS-CoV-2 infection in rhesus macaques and hamsters. Science 370, 1110-1115 (2020).

20. A. Schafer et al., Antibody potency, effector function, and combinations in protection and therapy for SARS-CoV-2 infection in vivo. The Journal of experimental medicine 218, e20201993 (2021).

21. M. S. Suthar et al., Rapid Generation of Neutralizing Antibody Responses in COVID-19 Patients. Cell reports. Medicine 1, 100040 (2020). 
22. E. Seydoux et al., Analysis of a SARS-CoV-2-Infected Individual Reveals Development of Potent Neutralizing Antibodies with Limited Somatic Mutation. Immunity 53, 98-105 e105 (2020).

23. D. F. Robbiani et al., Convergent antibody responses to SARS-CoV-2 in convalescent individuals. Nature 584, 437-442 (2020).

24. P. J. M. Brouwer et al., Potent neutralizing antibodies from COVID-19 patients define multiple targets of vulnerability. Science 369, 643-650 (2020).

25. J. M. Dan et al., Immunological memory to SARS-CoV-2 assessed for up to 8 months after infection. Science 371, 10.1126/science.abf4063 (2021).

26. L. B. Rodda et al., Functional SARS-CoV-2-Specific Immune Memory Persists after Mild COVID-19. Cell 184, 169-183.e117 (2021).

27. C. Gaebler et al., Evolution of antibody immunity to SARS-CoV-2. Nature, doi: 10.1038/s4158641021-03207-w (2021).

28. J. Seow et al., Longitudinal observation and decline of neutralizing antibody responses in the three months following SARS-CoV-2 infection in humans. Nat Microbiol 5, 1598-1607 (2020).

29. F. Muecksch et al., Longitudinal Serological Analysis and Neutralizing Antibody Levels in Coronavirus Disease 2019 Convalescent Patients. The Journal of infectious diseases 223, 389398 (2021).

30. L. Piccoli et al., Mapping Neutralizing and Immunodominant Sites on the SARS-CoV-2 Spike Receptor-Binding Domain by Structure-Guided High-Resolution Serology. Cell 183, 10241042.e1021 (2020).

31. T. L. Steffen et al., The receptor binding domain of SARS-CoV-2 spike is the key target of neutralizing antibody in human polyclonal sera. bioRxiv, 2020.2008.2021.261727 (2020).

32. C. O. Barnes et al., Structures of Human Antibodies Bound to SARS-CoV-2 Spike Reveal Common Epitopes and Recurrent Features of Antibodies. Cell 182, 828-842 e816 (2020).

33. L. Liu et al., Potent neutralizing antibodies against multiple epitopes on SARS-CoV-2 spike. Nature 584, 450-456 (2020).

34. J. Hansen et al., Studies in humanized mice and convalescent humans yield a SARS-CoV-2 antibody cocktail. Science 369, 1010-1014 (2020).

35. B. Ju et al., Human neutralizing antibodies elicited by SARS-CoV-2 infection. Nature 584, 115 119 (2020).

36. Y. Cao et al., Potent Neutralizing Antibodies against SARS-CoV-2 Identified by HighThroughput Single-Cell Sequencing of Convalescent Patients' B Cells. Cell 182, 73-84.e16 (2020).

37. A. J. Greaney et al., Complete Mapping of Mutations to the SARS-CoV-2 Spike ReceptorBinding Domain that Escape Antibody Recognition. Cell host \& microbe 29, 44-57.e49 (2021).

38. X. Chi et al., A neutralizing human antibody binds to the N-terminal domain of the Spike protein of SARS-CoV-2. Science 369, 650-655 (2020).

39. M. McCallum et al., N-terminal domain antigenic mapping reveals a site of vulnerability for SARS-CoV-2. bioRxiv, 2021.2001.2014.426475 (2021).

40. G. Cerutti et al., Potent SARS-CoV-2 Neutralizing Antibodies Directed Against Spike NTerminal Domain Target a Single Supersite. bioRxiv, 2021.2001.2010.426120 (2021).

41. G. Song et al., Cross-reactive serum and memory B cell responses to spike protein in SARSCoV-2 and endemic coronavirus infection. bioRxiv, 2020.2009.2022.308965 (2020).

42. C. Wang et al., Isolation of cross-reactive monoclonal antibodies against divergent human coronaviruses that delineate a conserved and vulnerable site on the spike protein. bioRxiv, 2020.2010.2020.346916 (2020).

43. F. Wu et al., A new coronavirus associated with human respiratory disease in China. Nature 579, 265-269 (2020).

44. L. R. Baden et al., Efficacy and Safety of the mRNA-1273 SARS-CoV-2 Vaccine. The New England journal of medicine 384, 403-416 (2021). 
45. K. S. Corbett et al., SARS-CoV-2 mRNA vaccine design enabled by prototype pathogen preparedness. Nature 586, 567-571 (2020).

46. F. P. Polack et al., Safety and Efficacy of the BNT162b2 mRNA Covid-19 Vaccine. The New England journal of medicine 383, 2603-2615 (2020).

47. A. B. Vogel et al., A prefusion SARS-CoV-2 spike RNA vaccine is highly immunogenic and prevents lung infection in non-human primates. bioRxiv, 2020.2009.2008.280818 (2020).

48. L. A. Jackson et al., An mRNA Vaccine against SARS-CoV-2 - Preliminary Report. The New England journal of medicine 383, 1920-1931 (2020).

49. E. E. Walsh et al., Safety and Immunogenicity of Two RNA-Based Covid-19 Vaccine Candidates. The New England journal of medicine 383, 2439-2450 (2020).

50. A. Rambaut et al. (virological.org, 2020), vol. 2021.

51. E. Volz et al., Transmission of SARS-CoV-2 Lineage B.1.1.7 in England: Insights from linking epidemiological and genetic data. medRxiv, 2020.2012.2030.20249034 (2021).

52. H. Tegally et al., Emergence and rapid spread of a new severe acute respiratory syndrome-related coronavirus 2 (SARS-CoV-2) lineage with multiple spike mutations in South Africa. medRxiv, 2020.2012.2021.20248640 (2020).

53. N. G. Davies et al., Estimated transmissibility and severity of novel SARS-CoV-2 Variant of Concern 202012/01 in England. medRxiv, 2020.2012.2024.20248822 (2020).

54. E. C. Sabino et al., Resurgence of COVID-19 in Manaus, Brazil, despite high seroprevalence. Lancet 397, 452-455 (2021).

55. N. R. Faria et al., Genomic characterisation of an emergent SARS-CoV-2 lineage in Manaus: preliminary findings. Virological.org, https://virological.org/t/genomic-characterisation-of-anemergent-sars-cov-2-lineage-in-manaus-preliminary-findings/586 (2021).

56. Á. O'Toole et al., Tracking the international spread of SARS-CoV-2 lineages B.1.1.7 and B.1.351/501 Y-V2. Virological.org, https://virological.org/t/tracking-the-international-spread-ofsars-cov-2-lineages-b-1-1-7-and-b-1-351-501y-v352/592 (2021).

57. K. K. Chan, T. J. C. Tan, K. K. Narayanan, E. Procko, An engineered decoy receptor for SARSCoV-2 broadly binds protein S sequence variants. bioRxiv, 2020.2010.2018.344622 (2020).

58. T. N. Starr et al., Prospective mapping of viral mutations that escape antibodies used to treat COVID-19. Science 371, 850-854 (2021).

59. L. Zhang et al., SARS-CoV-2 spike-protein D614G mutation increases virion spike density and infectivity. Nature communications 11, 6013 (2020).

60. B. Zhou et al., SARS-CoV-2 spike D614G change enhances replication and transmission. Nature, 10.1038/s41586-41021-03361-41581 (2021).

61. Z. Liu et al., Landscape analysis of escape variants identifies SARS-CoV-2 spike mutations that attenuate monoclonal and serum antibody neutralization. bioRxiv, 2020.2011.2006.372037 (2020).

62. A. Baum et al., Antibody cocktail to SARS-CoV-2 spike protein prevents rapid mutational escape seen with individual antibodies. Science 369, 1014-1018 (2020).

63. Q. Li et al., The Impact of Mutations in SARS-CoV-2 Spike on Viral Infectivity and Antigenicity. Cell 182, 1284-1294 e1289 (2020).

64. Y. Weisblum et al., Escape from neutralizing antibodies by SARS-CoV-2 spike protein variants. eLife 9, e61312 (2020).

65. E. C. Thomson et al., The circulating SARS-CoV-2 spike variant N439K maintains fitness while evading antibody-mediated immunity. bioRxiv, 2020.2011.2004.355842 (2020).

66. P. Wang et al., Increased Resistance of SARS-CoV-2 Variants B.1.351 and B.1.1.7 to Antibody Neutralization. bioRxiv, 2021.2001.2025.428137 (2021).

67. C. Graham et al., Impact of the B.1.1.7 variant on neutralizing monoclonal antibodies recognizing diverse epitopes on SARS-CoV-2 Spike. bioRxiv, 2021.2002.2003.429355 (2021).

68. X. Shen et al., SARS-CoV-2 variant B.1.1.7 is susceptible to neutralizing antibodies elicited by ancestral Spike vaccines. bioRxiv, 2021.2001.2027.428516 (2021). 
69. C. K. Wibmer et al., SARS-CoV-2 501Y.V2 escapes neutralization by South African COVID-19 donor plasma. Nature medicine, doi: 10.1038/s41591-41021-01285-x (2021).

70. Z. Wang et al., mRNA vaccine-elicited antibodies to SARS-CoV-2 and circulating variants. Nature, doi: 10.1038/s41586-41021-03324-41586 (2021).

71. Johnson \& Johnson Announces Single-Shot Janssen COVID-19 Vaccine Candidate Met Primary Endpoints in Interim Analysis of its Phase 3 ENSEMBLE Trial. https://www.prnewswire.com/news-releases/johnson--johnson-announces-single-shot-janssencovid-19-vaccine-candidate-met-primary-endpoints-in-interim-analysis-of-its-phase-13ensemble-trial-301218035.html (2021).

72. Novavax COVID-19 Vaccine Demonstrates 89.3\% Efficacy in UK Phase 3 Trial. https://ir.novavax.com/news-releases/news-release-details/novavax-covid-19-vaccinedemonstrates-893-efficacy-uk-phase-893 (2021).

73. M. Yuan et al., Structural basis of a shared antibody response to SARS-CoV-2. Science 369, 1119-1123 (2020).

74. N. C. Wu et al., An Alternative Binding Mode of IGHV3-53 Antibodies to the SARS-CoV-2 Receptor Binding Domain. Cell reports 33, 108274 (2020).

75. Y. Wu et al., A noncompeting pair of human neutralizing antibodies block COVID-19 virus binding to its receptor ACE2. Science 368, 1274-1278 (2020).

76. R. Shi et al., A human neutralizing antibody targets the receptor-binding site of SARS-CoV-2. Nature 584, 120-124 (2020).

77. S. Du et al., Structurally Resolved SARS-CoV-2 Antibody Shows High Efficacy in Severely Infected Hamsters and Provides a Potent Cocktail Pairing Strategy. Cell 183, 1013-1023.e1013 (2020).

78. N. K. Hurlburt et al., Structural basis for potent neutralization of SARS-CoV-2 and role of antibody affinity maturation. Nature communications 11, 5413 (2020).

79. J. Snijder et al., An Antibody Targeting the Fusion Machinery Neutralizes Dual-Tropic Infection and Defines a Site of Vulnerability on Epstein-Barr Virus. Immunity 48, 799-811 e799 (2018).

80. Y. Wan, J. Shang, R. Graham, R. S. Baric, F. Li, Receptor Recognition by the Novel Coronavirus from Wuhan: an Analysis Based on Decade-Long Structural Studies of SARS Coronavirus. Journal of virology 94, e00127-00120 (2020).

81. Y. Liu et al., Neutralizing Activity of BNT162b2-Elicited Serum - Preliminary Report. The New England journal of medicine, doi: 10.1056/NEJMc2102017 (2021).

82. K. Wu et al., Serum Neutralizing Activity Elicited by mRNA-1273 Vaccine - Preliminary Report. The New England journal of medicine, 10.1056/NEJMc2102179 (2021).

83. K. E. Kistler, T. Bedford, Evidence for adaptive evolution in the receptor-binding domain of seasonal coronaviruses OC43 and 229E. eLife 10, e64509 (2021).

84. P. A. Harris et al., Research electronic data capture (REDCap)--a metadata-driven methodology and workflow process for providing translational research informatics support. Journal of biomedical informatics 42, 377-381 (2009).

85. P. A. Harris et al., The REDCap consortium: Building an international community of software platform partners. Journal of biomedical informatics 95, 103208 (2019).

86. K. H. D. Crawford et al., Protocol and Reagents for Pseudotyping Lentiviral Particles with SARS-CoV-2 Spike Protein for Neutralization Assays. Viruses 12, https://doi.org/10.3390/v12050513 (2020).

87. C. L. Hsieh et al., Structure-based design of prefusion-stabilized SARS-CoV-2 spikes. Science 369, 1501-1505 (2020).

88. O. Dintwe et al., OMIP-056: Evaluation of Human Conventional T Cells, Donor-Unrestricted T Cells, and NK Cells Including Memory Phenotype by Intracellular Cytokine Staining. Cytometry. Part A : the journal of the International Society for Analytical Cytology 95, 722-725 (2019). 
medRxiv preprint doi: https://doi.org/10.1101/2021.02.05.21251182; this version posted March 10, 2021. The copyright holder for this preprint (which was not certified by peer review) is the author/funder, who has granted medRxiv a license to display the preprint in perpetuity.

89. H. Horton et al., Optimization and validation of an 8-color intracellular cytokine staining (ICS) assay to quantify antigen-specific T cells induced by vaccination. Journal of immunological methods 323, 39-54 (2007).

90. X. Wu et al., Rational design of envelope identifies broadly neutralizing human monoclonal antibodies to HIV-1. Science 329, 856-861 (2010). 
medRxiv preprint doi: https://doi.org/10.1101/2021.02.05.21251182; this version posted March 10, 2021. The copyright holder for this preprint (which was not certified by peer review) is the author/funder, who has granted medRxiv a license to display the preprint in perpetuity. It is made available under a CC-BY-NC-ND 4.0 International license .

\section{ACKNOWLEDGMENTS}

This work was supported by generous donations to Fred Hutch COVID-19 Research Fund, and to MJM from the Paul G. Allen Family Foundation, the Joel D. Meyers Endowed Chair, and NIAID UM1 AI068618-14S1, 2UM1 AI069481-15, and UM1A057266-S1. We thank the study participants for their dedication to this project, Trevor Bedford for assistance with the selection of spike mutations to include, Laura Richert Spuhler for assistance with figure preparation, Todd Haight and the Seattle Vaccine Unit specimen processing lab and staff for their service, and. L.S. and A.T.M. have filed a provisional patent application on the CV1, CV2-75 and CV30 SARSCoV-2 specific monoclonal antibodies. L.S., A.T.M., and A.F. have filed a provisional patent application on the CV3-1 SARS-CoV-2 specific monoclonal antibody.

\section{AUTHOR CONTRIBUTIONS}

Conceptualization, M.J.M., A.T.M., and L.S.; Investigation, Y-H. W., E.S., M.L., V.R., K.W.C., Z.M., M.N., L.J.H., A.J.M., M.J, J.F, G.M., H.G., and A.T.M; Writing - Original Draft, A.T.M., and L.S.; Writing - Review \& Editing, A.T.M., L.S., M.J.M., and E.S.; Funding Acquisition, L.S. and M.J.M; Resources, M.J.M., J.C., A.F.; Supervision, A.T.M.

\section{List of Supplementary Materials}

Figs. S1 to S8

Tables S1 to S4 